\section{Euroson 2016 i Leipzig}

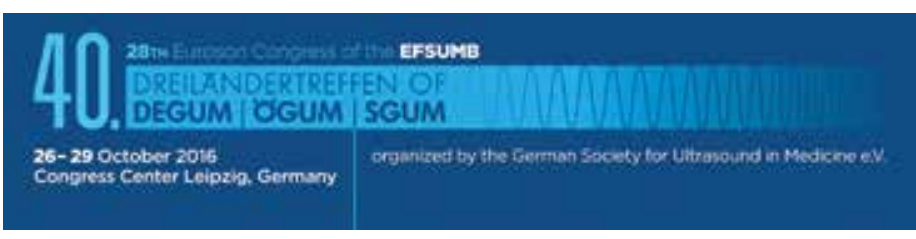

Den 26.-29. oktober gikk den 28. kongress av EFSUMB (European Federation of Societies for Ultrasound in Medicine and Biologiy) i Leipzig, Tyskland av stabelen. Som flere ganger tidligere var den $\mathrm{i}$ år organisert sammen med den 40. „Dreiländertreffen“ av de tre tyskspråklige ultralydforeningene i Tyskland (DEGUM), Østerrike (ØGUM) og Sveits (SGUM). Med over 2000 påmeldte dreide det seg om et stort arrangement.

Kongressen hadde som tidligere fokus på innovasjon, forskning og utdanning, samt flere kasustikkforelesninger, som trakk fulle hus spesielt på sesjonene i gynekologi og obstetrikk.

Trond Engjom, Odd Helge Gilja, Anesa Mulabecirovic, Kim Nylund, Nils Petter Oveland, Elisabeth K. Steinsvik, Eivind Valestrand og Svein Ødegård representerte Norge med hele 11 foredrag.

I "Young Investigator» sesjonen vant Norges representant Anesa Mulabecirovic prisen for beste kliniske presentasjon med foredraget «In vitro quantification of tissue elasticity using three shear wave elastography platforms on liver fibrosis phantoms». Prisen for den beste tekniske presentasjon fikk Emiel van Disseldorp fra Nederlandene.

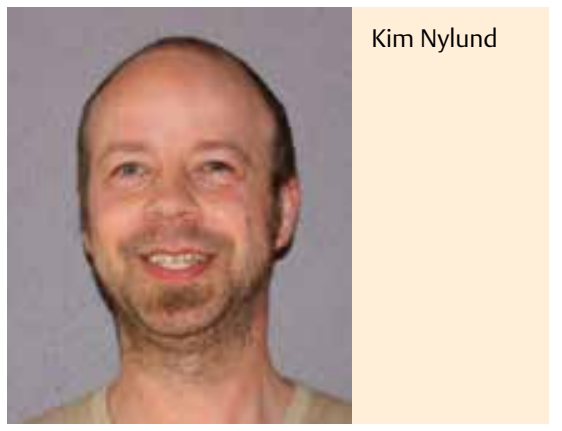

Kim Nylund fikk beste poster i sin sesjon for presentasjonen "Shear wave elastography of the bowel of patients with Crohn's disease». Prisen innebar at posteren ble hengt opp på vei inn til utstillingsområdet og fikk på denne måten ekstra oppmerksomhet.

Videre ble det gjort ære på Svein Ødegaard som ble valgt som EFSUMB fellow og fikk passende nok utdelt prisen under sesjonen "Gastrointestinal ultrasound - is it useful?» for en som har vist at det er nettopp det.

Den norske ultralydforeningen (NFUD) var godt representert i Leipzig med hele fem styremedlemmer. Ruth Stoklund Thomsen og Anette Hem Johnsen stilte som stedfortredere for leder på «Board of delegates meeting», dvs. generalforsamlingen. På møtet ble det blant annet informert om at Norge kommer til å søke om å få være arrangør for Euroson 2020 i Bergen.

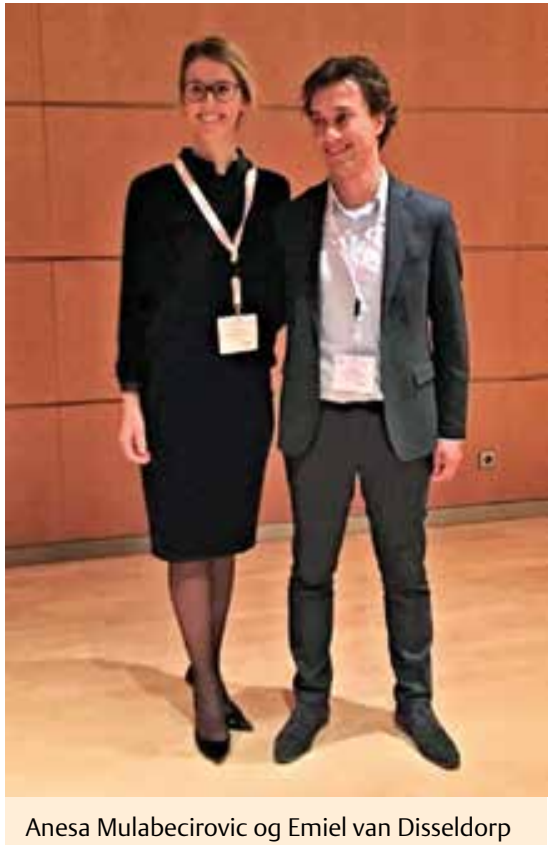

Norge er godt representert i sentrale EFSUMB posisjoner:

- Odd Helge Gilja er EFSUMB President.

- Roald Flesland Havre er medlem i «Publications Commitee».

- Kjell Åsmund (Pepe) Salvesen er medlem i «Safety committee».

- og Hilde Berner Hammer er medlem i «Educational and Professional Standards Committee».
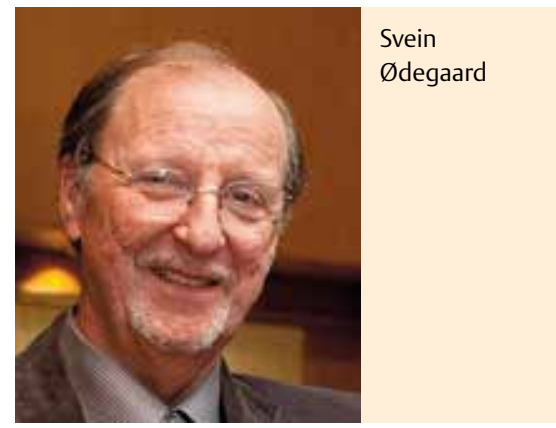